\title{
Biopsychosocial model in health care: reflections in the production of functioning and disability data
}

\author{
O modelo biopsicossocial no cuidado a saúde: reflexões sobre a \\ produção de dados sobre funcionalidade e incapacidade/deficiência
}

El modelo biopsicossocial en el cuidado a la salud: reflexiones sobre la producción de datos sobre funcionalidad e incapacidad/discapacidad

\author{
Diego de Sousa Dantas $^{[a]} \oplus$, Ana Paula Correa ${ }^{[\mathrm{b}]} \oplus$, Cassia Maria Buchalla ${ }^{[\mathrm{c}]} \oplus$, Shamyr Sulyvan \\ de Castro $^{[\mathrm{d}]}\left[\mathbb{C}^{\text {; Luciana Castaneda }}{ }^{[\mathrm{el}}\left[{ }^{*} *\right.\right.$
}

[a] Universidade Federal de Pernambuco, Recife, PE, Brazil

[b] Fundação Oswaldo Cruz (Fiocruz), Rio de Janeiro, RJ, Brazil

[c] Universidade de São Paulo (USP), São Paulo, SP, Brazil

[d] Universidade Federal do Ceará (UFC), Fortaleza, CE, Brazil

[e] Instituto Federal do Rio de Janeiro (IFRJ), Rio de Janeiro, RJ, Brazil

\begin{abstract}
Introduction: In the last decade, the inclusion of a functioning indicator in health care has been discussed on the international agenda. The strategies related to the implementation of these indicators are issues that involve health education, governance, and medical records. Objective: study aims to discuss the International Classification of Functioning, Disability and Health (ICF) potential as a useful tool to produce information on health care services. Method: As theoretical assumptions, the universal model of the ICF based on the biopsychosocial model was used. Results: When used as a health indicator, functioning data can measure the real effect of some health conditions in different life domains. Based on the reflections carried out and
\end{abstract}

\footnotetext{
* DSD: PhD, e-mail: diegodantas1@gmail.com APC: Doctoral Student, e-mail: anacarcorrea@gmail.com CMB: PhD, e-mail: cmbuchal@usp.br SSC: PhD, email: shamyrsulyvan@gmail.com LC: PhD, email: luciana.ribeiro@ifrj.edu.br
} 
theoretical foundations accessed, the study shows that the implementation of functioning indicators in periodical population health surveys and protocols of clinical documentation regardless the level of health service would be relevant for Patient Care Planning. Note that the group of functioning indicators should be proposed in a universal language and, therefore, ICF represents the most comprehensive model. Conclusion: Information regarding health status can be useful to enable health care management. Furthermore, ICF are essential to improve the documentation service of the health system and also can be used in planning and monitoring health care. It can also be used to collect disability data in surveys ensuring comparison among different surveys.

Keywords: International Classification of Functioning, Disability, and Health. Data Collection. Health Evaluation. Indicators of Health Services. Social Indicators.

\section{Resumo}

Introdução: Na última década, a inclusão de indicadores de funcionalidade na atenção à saúde tem sido discutida na agenda internacional. As estratégias relacionadas à implementação de indicadores de funcionalidade são uma questão que envolve educação, gestão e assistência à saúde. Objetivo: Este ensaio teórico tem como objetivo discutir o potencial da Classificação Internacional de Funcionalidade, Incapacidade e Saúde (CIF) como ferramenta útil na produção de informação para os serviços de saúde. Método: Utilizamos como pressupostos teóricos o modelo universal, a CIF. Nosso pressuposto baseia-se no modelo biopsicossocial do binômio saúde-doença. Resultados: Indicadores de funcionalidade podem medir o real impacto das condições de saúde em diferentes domínios da vida. A partir das reflexões realizadas e alicerces teóricos acessados, percebese que a implementação de indicadores de funcionalidade nos inquéritos populacionais periódicos em saúde e protocolos de registro para informação clínica, independentemente do nível de serviço de saúde, seria de grande interesse. Vale ressaltar que o grupo de indicadores de funcionalidade deve ser proposto em uma linguagem universal e, portanto, a CIF representa o modelo mais abrangente. Conclusão: $O$ indicador de funcionalidade pode ser útil para o gerenciamento da saúde. As informações sobre funcionalidade são essenciais para melhorar o planejamento e a qualidade dos serviços de saúde e podem ser usadas no planejamento e monitoramento dos cuidados de saúde; podem ser coletadas em pesquisas de saúde da população por ferramentas específicas; e poderiam ser produzidas usando a CIF como uma estrutura na coleta diária de informações sobre saúde.

Palavras-chave:ClassificaçãoInternacionaldeFuncionalidade,IncapacidadeeSaúde.ColetadeDados.Avaliação de Saúde. Indicadores de Serviços. Indicadores Sociais.

\section{Resumen}

Introducción: En la última década, la inclusión de indicadores de funcionamiento en la atención de salud se ha discutido en la agenda internacional. Las estrategias relacionadas con la implementación de los indicadores de funcionamiento son un tema que involucra educación, gestión y atención médica. Objetivo: Este ensayo teórico tiene como objetivo discutir el potencial de Clasificación Internacional del Funcionamiento, de la Discapacidad y de la Salud (CIF) como una herramienta útil para producir información en los servicios de atención médica. Método: Utilizamos como suposiciones teóricas el modelo universal de la CIF con base en el modelo biopsicosocial del binomio salud-enfermedad. Resultados: Los indicadores de funcionamiento pueden medir el impacto real de las condiciones de salud en diferentes dominios de la vida. Con base en las reflexiones realizadas y los fundamentos teóricos, se observa que sería esencial la implementación de indicadores de funcionamiento en las encuestas periódicas de salud de la población y en los protocolos de registro para la información clínica, independiente del nivel del servicio de salud. Vale la pena mencionar que el grupo de indicadores de funcionamiento debe proponerse en un lenguaje universal y, por lo tanto, CIF representa el modelo más completo. Conclusión: El indicador de funcionamiento puede ser útil para la gestión de la salud. Las informaciones sobre funcionamiento son esenciales para mejorar la planificación y la calidad de los servicios 
de salud y se puede utilizarlas para planificar y monitorear los cuidados en salud; y se puede recopilarlas en encuestas de salud de la población mediante herramientas específicas; y podría recopilarse utilizando la CIF como herramienta en la recopilación diaria de información sobre salud.

Palabras clave: Clasificación Internacional del Funcionamiento, de la Discapacidad y de la Salud. Recolección de Datos. Evaluación en Salud. Indicadores de Servicios. Indicadores Sociales.

\section{Introduction}

\section{Contextualization of Functioning models}

The interest in describing experiences regarding disability appeared in the scientific literature in the 1960s. The first model was the biomedical, which is composed of four components: active pathology, lesion, functional impairment, and disability. This model proposes a unidirectional and linear interaction from the active pathology to the occurrence of negative experience [1]. This model was the most cited and criticized over the years, mainly by its linearity [2].

In response to the reductionism of the biomedical model, the associations of people with disabilities assembled and proposed the social model. According to the social model, disability is pronouncing an inadequacy between the body and their environment [3]. Other models were introduced between the two previous models; they are often derived or related to them as the models proposed by the International Classification of Impairments, Disabilities, and Handicaps (ICIDH) [4], the National Center for Medical Rehabilitation Research (NCMRR model) [5], and the Disability Creation Process (DCP) [6].

The International Classification of Functioning, Disability, and Health (ICF) created a more robust and grounded proposal in the biopsychosocial model of understanding. In this model, the experiences involving health condition, body function and structures, activities, participation, and contextual factors (personal and environmental) are considered [7]. In ICF, functioning indicates the positive aspects of the interaction between the individual and its context (personal and environmental factors). Disability is an umbrella term for impairments, activity limitations, or participation restrictions [7]. The World Health Organization (WHO) stimulates the ICF use to establish a common language to improve the communication in health care [8].
This article proposes a discussion on the potential of ICF as a useful tool for producing information in health care services.

\section{Method}

This study was based on the biopsychosocial model to discuss the generation of functioning information-theoretically. Some scientific elements related to the process of information production on functioning will be covered and discussed in the next sections.

\section{Results}

Functioning indicators in health information: a global agenda

Health organizations have been involved in growing challenges from epidemiological and demographic changes in the last decades. Stakeholders from governments, managers, companies, and users expect that health problems can be overcome with technological innovations. The systematic collection of health information can be aligned with the perspective of Innovation [9]. Health information -initially collected in environments involving the routine of health services-has the potential to increase efficiency and to considerably reduce some costs. Health systems, when emphatically present in services, can generate a set of primary data that express the health status [10].

Supporting new indicators, the World Health Organization (WHO) argues that there is a wide range of health information, more significant and more diverse than the classic indicators of mortality and morbidity. This scenario justifies the efforts to insert functioning information as a third health indicator [11]. The experience of functioning contemplates the "lived experience of health" or how the condition of health unfolds in everyday life. It concerns the autonomy of people in their daily lives, 
going beyond the perception of body structures and functions while better understanding the relations between biomedical information with activities and participation domains, as well as the influence of environment and personal factors. The relevance of this measuring in the population, although complex and challenging, is undeniable, and its consequences can work as a subsidy to improve universal health systems [12].

Several initiatives can improve the quality of health information, such as standardization of the terminologies used, easy access to information, dissemination of the processes involved, as well as efforts in production, data analysis and distribution of results based on health actions [13]. In many situations, the continuity of improving health information systems can be affected by economic, political, and logistical factors. Difficulties such as lack of integration in the information produced, disjointed and disintegrated systems, duplicate production and redundant information, as well as problems in accessing and disseminating information - especially in low- and middle-income countries - , may contribute to a fragmentation of data that compose the health information systems [14].

The discussion about the insertion of data related to functioning in different levels of documentation in health care becomes increasingly relevant in the last decade [15]. Thus, this article proposes a discussion based on the following guiding questions:

1) How important is the information on functioning to justify the targeting of resources for its systematic collection?

2) Is functioning information essential for patient care planning?

3) How to use functioning information in disability surveys?

4) How to systematically collect and record functioning information in clinical practice?

How important is the information on Functioning to justify the targeting of resources for its systematic collection?

It is essential to understand the need to dissociate concepts of health status to include functioning among the classic indicators. Healthy-according to the biomedical model-is the intrinsic capacity of the person, and the occurrence of problems mainly in the functions and structures of the body is a way to assess the status of health. This condition might cause limitations in activities and restrictions on participation, as pointed before. Therefore, the biopsychosocial perspective includes all factors previously mentioned, but it also includes the context, extending it to the environment and personal factors, in a more realistic way of the lived experience of health until then available from 2001 [16].

By including functioning as a health indicator, an undeniable advance towards studying beyond the occurrence of death, frequency, and distribution of health conditions in a population occurs. Consequently, it would be possible to develop data on health status [17]. The inclusion of social assurance indicators in line with the biopsychosocial model can enable the observation of relationships networks between contextual factors (environmental and personal), biological factors (body structures and functions), and the execution of activities and social participation [18].

It should be stressed that in the course of life, a significant part of the population may undergo many experiences related to health conditions. These can be diseases, disorders, injuries, and even subjective experiences [19]. They may manifest acutely or chronically, mildly or intensely. Health conditions influence individuals in different ways and the sole effect can be as substantial as the health condition itself.

In the case of being affected by a disease, people may present all the specific symptoms. However, in addition to the characteristic symptoms of the disease itself, a subject can also present activity limitations, restrictions on participation, and experience environmental barriers or facilitators. These situations might be associated with the health condition, but it can also interfere in the autonomy and, therefore in the individual's functioning. For example, patients with low back pain (code M54.5, according to the International Classification of Diseases - ICD-10) can experience much more than just lower back pain. The low back pain can compromise body functions such as sleep, exercise tolerance, mobility, stability, strength, and muscle tone. Body structures such as the spinal cord or trunk structure may also be affected. Activities and participation such as maintenance and change of body position, walking, going to the bathroom, dressing, 
and working may be affected due to low back pain [20]. How can the clinicians know about activity and participation if the documentation is based on health conditions, body functions and body structure? Would clinicians have enough information on patient care planning? Regarding the biomedical model, the International Classification of Functioning, Disability, and Health can be a more comprehensive theoretical framework for establishing therapeutic goals that promote participation. Combining data from ICD and ICF, as suggested by WHO, makes the patient picture closer to the reality of the facts [21].

Mortality and morbidity indicators are traditionally used as standard measures of surveys. The mortality refers to survival time or risk of dying; morbidity describes how diseases are distributed at the population level. ICD can code both. However, a health condition affects many aspects of people's lives. The functioning was proposed as a third health indicator trying to get more accurate data about how the health conditions lead to adverse effects in activity and participation. Functioning would not only be a health indicator, but it could be a strong structure to describe the effect and service delivery of health interventions [11].

Is Functioning information essential for health care?

The importance and essentiality of functioning information lie in the fact that it can be used at primary, specialized and hospital levels of health care services. Therefore, its importance is threefold: at the micro-level of health care, users can benefit from the provision of adequate rehabilitation support and orientation. Individualized therapeutic interventions applicable to reality, regardless of the health care level (primary, secondary and tertiary) and the treatment phase (acute, post-acute, and chronic); at the mid-level, it can be used to describe the analysis of a patient situation for the multi-professional clinicians. At the macro-level, health policies can use the information on functioning to monitor the health care offered, especially in rehabilitation services [22].

How to use disability data in surveys?

There is a gap in disability data across the world. WHO recently proposed the use of the Model Disability Survey (MDS). An ICF instrument explicitly designed for the systematic collection of functioning in surveys [23]. Moreover, for clinical practice, WHO also proposes the use of the World Health Organization Disability Assessment Schedule - WHODAS 2.0, for collecting epidemiological data [24]. The ICD-11 has incorporated the MDS and WHODAS as tools to measure Functioning in the Supplementary Section on Functioning Assessment, thus showing the relevance and usefulness of the ICF [25].

The logic of a minor view on the disability effect in daily lives of people with disability is evident in the way in which national surveys structure their assessments [26]. As an example, in the Brazilian national health survey, the prevalence of physical disability was estimated with only one variable: the "difficulty in walking about 100 meters" [27]. By using such an approach, we have a populationbased survey that present to us only a superficial look. This approach restricts a broad concept, multifaceted and with interrelated elements, to just one aspect: the difficulty (limitation) that the population has in accomplish mobility-related activities. Thus, survey data cannot estimate the actual prevalence of disability, although it can indicate the occurrence of the limitation for mobilityrelated activities. This traditional approach reduces components that interfere with functioning experiences while it enhances activities that assess capacity and performance. Consequently, they persist in neglecting contextual factors such as environmental barriers.

Reliable and internationally comparable data on disability surveys are often not available, and when they are, they do not necessarily present the reality. Estimates of the prevalence vary dramatically, for example, from less than $1 \%$ of disability in Kenya and Bangladesh to $14.5 \%$ in Brazil [28]. Different definitions, different data collection methodologies, and variations in the quality of the methodological study designs can explain this divergence [29]. The country's income and the prevalence of disability found may be directly related. High-income countries tend to present a higher prevalence than lowand middle-income countries. What justifies this discrepancy? Do low- and middle-income countries have better health conditions than high-income countries, or is there an underestimation of the prevalence in low-income countries? The answer to such questions will depend on the effort applied to include the ICF by using the MDS in the national 
surveys as well as on the use of the definition of disability as a standardized and adequate term.

How to systematically collect and record Functioning information in the health care process?

The question above may be the most complex and challenging guiding question. There are substantial practical obstacles that must be addressed to guide the collection of health data. To operationalize the insertion of information on functioning, ICF, stands out as the gold standard framework available for a reference system [15].

The ICF properties recognize that every human being may experience, at some point in their life, a health loss and thus experience some disability. Disability is not only relevant or restricted to a narrow or minority group of people. According to WHO, they are more than one billion people, which represents around $15 \%$ of the world population [30]. By shifting the focus that a health problem inevitably leads to disability, ICF places all health conditions on an equal level, enabling information to be compared using a standard metric the "metrics of experiences" [31].

The inclusion of functioning information in routine care may be based on two relevant topics: 1) concept equivalence - approaching the same domain by different instruments. ICF codes offer the opportunity to standardize concepts; 2) equivalence of scores. Qualifiers must be corresponded and measured by the same unit, presenting the same numerical meaning [32]. In the subsequent step, the process of identifying standard content for specific ICF codes can be performed [33]. With the use of Linking Rules, it is possible to generate a direct interface of the outcome assessment used in data collection with a structured information system with functioning data. The concepts comprised in health information can be converted, resulting in the corresponding ICF codes [33].

\section{Final notes}

Therefore, answering directly the four guiding questions of the study, \# 1 the use of an indicator of functioning will enable health management to obtain health information beyond the data regarding deaths and frequency and distribution of health conditions; \#2 It is essential to health care, to provide an adequate support to rehabilitation and orientation as well as patient-centered therapeutic interventions. The measurement of clinical patient outcomes of participation can improve autonomy and it is high indicated to monitoring health care offered, especially in rehabilitation services; \#3 disability data can be collected in population health surveys by specific tools proposed by WHO (MDS and WHODAS); \#4 with the use of the linking rules, it is possible to improve medical records.

The generation of data can be provided by periodic health surveys to identify the profile of the population health status [23] and clinical information from different health care levels can be integrated with ICF codes [34]. The general information documented in health care settings should quantify the creation of a talking-culture about activity of participation and contextual factors. Furthermore, it can contribute to improve clinical decision-making during continuous health care [35].

The ICF has been recognized internationally as a useful tool and it is becoming a global trend [36]. The previously reported experiences demonstrate that it is used by health professionals to improve communication [37] and to enable the creation of more effective therapeutic goals [38].This tool can be a roadmap to define specific objectives as well as appropriate interventions. Incorporating the ICF in different levels of health care will contribute to the diffusion of the biopsychosocial model [39].

In addition to the discussion, the increased resilience of health services facing the current economic, environmental, social and epidemiological challenges focuses on improving the accountability for resource allocation and in the necessity to measure the intervention results. This discussion highlights a global issue about properties of health information [40]. Requirements such as data quality, coverage, efficiency, and quality of care are fundamental for universal health systems, and the new epidemiological profile can be able of adapting to new changes. The production of primary data by health surveys is the main source for population data and it should be used to reduce gaps in the collection of health information in countries where routine data is not filled by vital statistics [41]. The report produced by surveys makes it possible to optimize the systems by making them more responsive and focused on the perception of the population about the access and quality of health services offered. 
The improvement of health quality information and the effort employed to improve the health conditions can be more productive with the language, model and system of the ICF. Then, it should be treated as a priority [11]. Increasing expansiveness and coverage of health information systems with the insertion of this data is not limited to investments with expensive technologies. It is essential to recognize the role that technology can play. However, performance is not just a matter of technology by itself [42].

\section{Conclusion}

Allied to investing in information technology in different clinical care, the inclusion of a functioning perspective into health education proposes can be an outlet for the predominant biomedical point of view. Also, adding ICF in health policy and its implementation can bring positive benefits to users, managers, and health care services. However, this is not a unique recipe for success. It is a paradigm shift - the paradigm of health care driven by the biopsychosocial model.

\section{References}

1. Jette AM, Keysor JJ. Disability models: implications for arthritis exercise and physical activity interventions. Arthritis Rheum. 2003;49(1):114-20.

2. Jette A. Toward a common language for function, disability, and health. Phys Ther. 2006;86(5):726-34.

3. Goering S. Rethinking disability: the social model of disability and chronic disease. Curr Rev Musculoskelet Med. 2015;8(2):134-8.

4. World Health Organization. International Classification of Impairments, Disabilities, and Handicaps. Geneva: WHO; 1980.

5. National Institutes of Health. Research Plan for the National Center for Medical Rehabilitation Research. Bethesda: NIH; 1993.

6. Levasseur M, Desrosiers J, St-Cyr TD. Comparing the disability creation process and International Classification of Functioning, Disability, and Health Models. Can J Occup Ther. 2007;74:233-42.
7. World Health Organization. ICF Checklist Version 2.1a, Clinician Form for International Classification of Functioning, Disability, and Health. Geneva: WHO; 2003.

8. Dorjbal D, Cieza A, Gmünder HP, Scheel-Sailer A, Stucki G, Üstün TB, et al. Strengthening quality of care through standardized reporting based on the World Health Organization's reference classifications. Int J Qual Heal Care. 2016;28(5):622-33.

9. World Health Organization. WHO global disability action plan 2014-2021: better health for all people with disability. Geneva: WHO; 2015.

10. De Nardi P, Giorgi G, La Manna A, Traversoni S, Giardini A. Towards a baseline ontology for information technology in rehabilitation medicine: the nomenclator of the rehabilitation procedures. G Ital Med Lav Ergon. 2019;41(2):112-6.

11. Stucki G, Bickenbach J. Functioning: the third health indicator in the health system and the key indicator for rehabilitation. Eur J Phys Rehabil Med. 2017;53(1):134-8.

12. Stucki G, Zampolini M, Juocevicius A, Negrini S, Christodoulou N. Practice, science and governance in interaction: European effort for the system-wide implementation of the International Classification of Functioning, Disability and Health (ICF) in Physical and Rehabilitation Medicine. Eur J Phys Rehabil Med. 2017;53(2):299-307.

13. World Health Organization. Developing health management information systems: a practical guide for developing countries. Manila: WHO Regional Office for the Western Pacific; 2004.

14. Mutale W, Chintu N, Amoroso C, Awoonor-Williams K, Phillips J, Baynes C, et al. Improving health information systems for decision making across five sub-Saharan African countries: implementation strategies from the African Health Initiative. BMC Health Serv Res. 2013;13 (Suppl2):S9.

15. Madden RH, Bundy A. The ICF has made a difference to functioning and disability measurement and statistics. Disabil Rehabil. 2019;41(12):1450-62. 
16. Stucki G, Cieza A, Melvin J. The International Classification of Functioning, Disability and Health (ICF): a unifying model for the conceptual description of the rehabilitation strategy. J Rehabil Med. 2007;39(4):279-85.

17. Sabariego C, Oberhauser C, Posarac A, Bickenbach J, Kostanjsek N, Chatterji S, et al. Measuring disability: comparing the impact of two data collection approaches on disability rates. Int J Environ Res Public Health. 2015;12(9):10329-51.

18. Talo SA, Rytökoski UM. BPS-ICF model, a tool to measure biopsychosocial functioning and disability within ICF concepts: theory and practice updated. Int J Rehabil Res. 2016;39(1):1-10.

19. Harari YN. Homo deus: a brief history of tomorrow. New York: Harper; 2017.

20. Fréz AR, Binda AC, Dubiela A, Daniel CR, Flor Bertolini GR, Ruaro JA, et al. Functional profile of active older adults with low back pain, according to the ICF. Rev Bras Med Esporte. 2016;22(4):252-5.

21. Di Nubila HBV, Buchalla CM. O papel das classificações da OMS - CID e CIF nas definições de deficiência e incapacidade. Rev Bras Epidemiol. 2008;11(2):324-35.

22. Organização Mundial da Saúde. Como usar a CIF: um manual prático para o uso da Classificação Internacional de Funcionalidade, Incapacidade e Saúde (CIF): versão preliminar para discussão: outubro de 2013. Brasília, DF: OMS; 2013.

23. Cieza A, Sabariego C, Bickenbach J, Chatterji S. Rethinking disability. BMC Med. 2018;16(1):10-4.

24. World Health Organization. Measuring health and disability: manual for WHO Disability Assessment Schedule WHODAS 2.0. Geneva: WHO; 2010.

25. Selb M, Kohler F, Meri M, Nicol R, Riberto M, Stucki G, et al. ICD-11: a comprehensive picture of health, an update on the ICD-ICF joint use iniciative. J Rehabil Med. 2015;47(1):2-8.

26. Castro SS, Castaneda L, Araújo ES, Buchalla CM. Aferição de funcionalidade em inquéritos de saúde no Brasil: discussão sobre instrumentos baseados na Classificação Internacional de Funcionalidade, Incapacidade e Saúde (CIF). Rev Bras Epidemiol. 2016;19(3):679-87.
27. Castaneda L, Castro SS, Bahia L. Disability constructs of the Brazilian National Household Survey (PNAD): an analysis based on the International Classification of Functioning, Disability and Health (ICF). Rev Bras Estud Popul. 2014;31(2):419-29.

28. Mont D. Viewpoint measuring health and disability. Lancet. 2007;369:1658-63.

29. Groce NE, Mont D. Counting disability: emerging consensus on the Washington Group questionnaire. Lancet. 2016;5(7):e649-50.

30. World Health Organization. World report on disability 2011. Geneva: WHO; 2011.

31. Stucki G, Bickenbach J, Gutenbrunner C, Melvin J. Rehabilitation: the health strategy of the 21st century. J Rehabil Med. 2018;50(4):309-16.

32. Prodinger B, Ballert CS, Brach M, Brinkhof MWG, Cieza A, Hug K, et al. Toward standardized reporting for a cohort study on functioning: The Swiss Spinal Cord Injury Cohort Study. J Rehabil Med.2016;48(2):189-96.

33. Cieza A, Fayed N, Bickenbach J, Prodinger B. Refinements of the ICF Linking Rules to strengthen their potential for establishing comparability of health information. Disabil Rehabil. 2019;41(5):574-83.

34. Constand MK, MacDermid JC. Applications of the International Classification of Functioning, Disability and Health in goal-setting practices in healthcare. Disabil Rehabil. 2014;36(15):1305-14.

35. Cieza A, Boldt C, Ballert CS, Eriks-Hoogland I, Bickenbach JE, Stucki G. Setting up a cohort study on functioning: deciding what to measure. Am J Phys Med Rehabil. 2011;90(11 Suppl 2):17-28.

36. Castaneda L, Bergmann A, Bahia L. The International Classification of Functioning, Disability and Health: a systematic review of observational studies. Rev Bras Epidemiol. 2014;17(2):437-51.

37. Tempest S, Jefferson R. Engaging with clinicians to implement and evaluate the ICF in neurorehabilitation practice. NeuroRehabilitation. 2015;36(1):11-5.

38. Gonçalves AV, Jácome CI, Demain SH, Hunt KJ, Marques AS. Burden of treatment in the light of the international classification of Functioning, Disability and health: a "best fit" framework synthesis. Disabil Rehabil. 2017;39(13):1253-61. 
39. Jacob T. The implementation of the ICF among Israeli rehabilitation centers: the case of physical therapy. Physiother Theory Pr. 2013;29(7):536-46.

40. Stucki G, Bickenbach J, Melvin J. Strengthening rehabilitation in health systems worldwide by integrating information on functioning in national health information systems. Am J Phys Med Rehabil. 2017;96(9):677-81.

41. Brandt DE, Ho PS, Chan L, Rasch EK. Conceptualizing disability in US national surveys: application of the World Health Organization's (WHO) International Classification of Functioning, Disability, and Health (ICF) framework. Qual Life Res. 2014;23(10):2663-71.
42. Stephenson R, Richardson B. Building an interprofessional curriculum framework for health: a paradigm for health function. 2008;13(4):547-57.

Received in 02/28/2019

Recebido em 28/02/2019

Recibido en 28/02/2019

Approved in 11/26/2019

Aprovado em 26/11/2019

Aprobado em 26/11/2019 